УДК 821.161 .2

Новиков Анатолій, доктор філологічних наук, професор, завідувач кафедри української мови, літератури та методики навчання Глухівський національний педагогічний університет імені Олександра Довженка

\title{
«...ЗВЕТЬСЯ МІЙ ХУТІР ЗАТИШОК»: ОСТАННІ РОКИ ЖИТТЯ МАРКА КРОПИВНИЦЬКОГО
}

У розвідизі висвітлюються останні роки життя Марка Кропивницького, коли він мешкав у своїи садибі на Харківщині. Акцентується на тому, що на межі XIX - XX ст. драматург із великим успіхом займався на своєму хуторі Затишок сільським господарством, влаштував потужний культурний осередок, у якому побувало чимало відомих особистостей, започаткував одну з перших у тодішній краӥні школу з украӥнською мовою навчання, дитячу трупу, аналогів якій не було в історії світового театру, оскільки в ролі акторів у ній виступали селянські діти. Разом із начіональним професійним театром, який метр на теренах підросійської Украӥни заснував дещэо раніше, все ие сприяло утвердженню національної культури, наводило україниів на думку про створення власної держави.

Ключові слова: хутір Затишок, украӥнська мова, дитячий театр, п'єси-казки, Заньковецька, Карпенко-Карий.

\section{“...My village is called Zatyshok": the last years of Marko Kropyvnytskyi}

The article highlights the last years of Marko Kropyvnytskyi life when he lived in his homestead in Kharkiv region. It is emphasized that at the turn of the XIX -XX centuries the playwright successfully practiced agriculture in his small village Zatyshok, here he organized a powerful cultural center which many well-known personalities visited. There in that time country he founded one of the first school with a Ukrainian language of teaching as well as organized a 
children theater group which did not have any analogues in the history of the world theater as peasants' children acted there as actors. This theater as well as the national professional theater which was founded by M. Kropyvnytskyi earlier on the territory of Ukraine which at that time was incorporated in the Russian Empire promoted the assertion of the national culture, led the Ukrainians to think about the development of their own state.

Key words: small village Zatyshok, Ukrainian language, children theater, plays and fairytales, Zan'kovets'ka, Karpenko-Karyi.

У пантеоні національної культури Марко Кропивницький посідає одне 3 найпочесніших місць. Це обумовлено тим великим внеском, який він зробив у розвиток національного театру як драматург, актор i режисер, як засновник уславленого театру корифеїв, 3 появою якого восени 1882 року, за великим рахунком, і розпочинається історія українського професійного театру в підросійській Україні. Бездоганно володіючи всіма театральними професіями, він створив потужну театральну школу. Першими його учнями були такі відомі згодом майстри сцени, як Микола Садовський, Панас Саксаганський, Марія Заньковецька, Ганна Затиркевич-Карпинська, Марія Садовська-Барілотті.

Менш відомі останні роки життя майстра, коли він мешкав на Харківщині, у своїй садибі на хуторі з поетичною назвою Затишок.

Творчість М. Кропивницького в різні часи досліджували Микола Йосипенко, Петро Киричок, Іван Пільгук, Ростислав Пилипчук та чимало інших відомих літературознавців і театрознавців. Останні ж роки життя метра знайшли відображення здебільшого у працях автора цієї статті.

Мета розвідки - висвітлити останній, слобожанський період життя Марка Кропивницького.

1890 року, уже будучи в зеніті слави, Кропивницький оселяється на хуторі Затишок, «за 120 верст від Харкова і за 20 верст від повітового міста Куп’янська», недалеко від села Сподобівки (тепер Шевченківського району, Харківської області). Задум купити хутір з’явився у драматурга ще на початку 1880-х років. Мабуть, невдовзі після того нещасного випадку, що стався з ним 2 лютого 1882 року на сцені Київського драматичного театру, коли під час спектаклю актора було серйозно травмовано декорацією, котра несподівано зірвалась і вдарила його по голові. «...Київський удар в голову, - згадує 
Кропивницький 2 травня 1882 року в листі до свого товариша по Бобринецькому повітовому училищу Єгора Мячикова, - став досить безцеремонно й частенько нагадувати про себе то запамороченням, то дзвоном у вухах. Лікарі радять їхати у глухомань: від шуму кам'яних мостових та затхлого міського повітря; радять пити молоко, купатись у ставку; ходити босоніж по росі, рано лягати (якнайменше сидіти при світлі свічок та ламп) i вставати до схід сонця. Ось чому літо я вирішив прожити в хуторах» [Кропивницький $1960: 332]$.

Проте різні обставини (передусім особистого характеру) заважали Кропивницькому втілити в життя свою мрію. Про це йдеться в листі (від 8 листопада 1885 року) до того ж Мячикова. «Обставини склалися таким чином, - зазначає письменник, - щзо я маю відкласти на невизначений термін думку про купівлю хутора. Розповісти тобі про причину $і$ важко, й ніяково; власне, опікування більш складною справою виключає будь-які інші турботи...» [Кропивницький $1960: 345]$.

Відповідь на це питання знаходимо у листі Кропивницького (від 3 грудня 1885 року) до його харківського приятеля Павла Карпинського. У цьому своєму посланні драматург сповіщає про те, що до нього в Одесу, де він був на гастролях, несподівано приїхала колишня пасія, актриса Лідія Квітка (Тимківська), в результаті роману 3 якою у них народився хлопчик (Згодом відомий як актор Павло Тимківський) [Кропивницький 1960 : 345-346]. Отже, потрібно було передусім уладнати цю справу.

Здійснити свою давню мрію вдається Кропивницькому лише влітку 1889 року. Купив хутір письменник у поміщика Березовського, і називався він тоді Сашиним. Затишком став іменувати його митець за кілька років потому. Першу звістку про нову назву хутора знаходимо у листі драматурга до М. Садовського від 4 березня 1895 року [Кропивницький 1960 : 430]. Звідки взялася ця поетична назва - неважко здогадатись. Після тривалих і виснажливих гастролей це казкове місце, де жили найдорожчі для письменника люди (дружина, діти й старенька матуся), було справжнім затишком від життєвих негараздів. Тут 
серед простих людей на лоні чудової української природи Кропивницькому завжди добре і відпочивалось, і працювалося.

Переїхав на свій хутір Кропивницький навесні 1890 року разом із дружиною Надією Василівною, матір'ю Капітоліною Іванівною та дворічною донькою Олександрою (син Володимир та друга донька Ольга народились уже в Затишку). За садибу й землю йому довелося заплатити дев’ять тисяч рублів. Окрім того, він змушений був узяти на себе десять тисяч п’ятсот рублів банківського боргу. На той час це була досить велика сума, і сплатити їі нелегко було навіть такому уславленому актору, як Кропивницький, який отримував за свою працю відносно високі гонорари. Не раз потім турботи про термінові платіжні внески Земельному банку, де був заставлений хутір, свідчить драматургів син, «примушували Надію Василівну проводити безсонні ночі, причому сам Марко Лукич у таких випадках звичайно впадав у паніку $i$ навіть лякав дружину Сибіром» [Кропивницький 1968 : 23-24]. Наскільки це було серйозно, видно хоча б із того, що за банківський борг Затишок назначався у публічний продаж. Торг мав відбутись 21 червня 1895 року. «...Ледве-ледве викрутився; не знаю, як викручусь з виданням творів, бо й на пера треба грошей $і$ на друк» [Кропивницький 1960 : 447], - поскаржиться через кілька днів потому митець у листі до Бориса Грінченка.

Маєток знаходився у мальовничий місцині. Тут було і чимало гаїв та лісів 3 поетичними галявинами, i ставок 3 красунями вербами, посадженими господарем садиби, i великий сад 3 різноманітними фруктовими та декоративними деревами, котрі також посадив Кропивницький, і багато чого іншого, що робило хутір дуже привітним, майже казковим.

Головна незручність для Кропивницького у перші роки життя на хуторі що поблизу не було залізниці. Тому до Харкова доводилось їхати кіньми майже цілу добу. Можна уявити, якою була ця подорож у бездоріжжя. Та ось наприкінці 1895 року до ладу стає нова залізниця Харків - Балашов, що пролягла за десять верст від Затишка (станція Старовірівка), і вся поїздка 
скорочується до чотирьох годин. Це дає змогу Кропивницькому, який у ці роки постійно гастролював, набагато частіше бувати на хуторі.

Зі споруд у садибі був старий дерев’яний двоповерховий будинок із цегляним низом, що залишився від попередніх власників, і новий - кам'яний, збудований драматургом у перші роки мешкання в Затишку. У дворі знаходилися стайня, сарай для худоби та інші необхідні для господарства будівлі. «Новий будинок - під залізною зеленою покрівлею і 3 мезоніном, згадує син письменника, - мав дуже привабливий вигляд. Він був так вдало розташований, що можна було нам від’їхати кілька верст по сеньківському чи бугаївському шляху, коли вся садиба вже давно зникла за обрієм, як, раптом оглянувшись, ми знову бачили вдалині мальовничу панораму хутора 3 будинком, що яскраво виділявся» [Кропивницький 1968 : 26].

Кропивницькі, звичайно, жили у новому будинку. Одна 3 найбільших кімнат була відведена під кабінет драматурга. На стінах у ній висіло безліч картин, у тому числі й копія «Запорожців» Іллі Рєпіна, виконана олійними фарбами господарем обійстя. Великий килим над диванчиком був увішаний старовинною зброєю: шаблями, кинджалами, пістолями та сучасними рушницями.

У старому будинку майже постійно, особливо влітку, жили родичі або знайомі Кропивницького, здебільшого актори. Протягом двох років у гостинній садибі драматурга мешкали родичі Тараса Шевченка, діти небоги Ірини Ковтунової (Палажка, Гапка й Гнат), яким тут було надано необхідну матеріальну й медичну допомогу. Незрідка гостював у Затишку і добрий знайомий митця відомий український історик, ректор Харківського університету професор Дмитро Багалій, а також його дружина й діти. Донька вченого, Ольга, залишила яскраві спогади про Кропивницького. А сам він чимало теплих слів присвятив митцеві на сторінках своєї фундаментальної праці «История города Харькова за 250 лет его существования».

На особливу увагу заслуговує приїзд на хутір уславлених майстрів української сцени Івана Карпенка-Карого й Миколи Садовського. Сталося ця 
подія навесні 1900 року, і пов’язана вона була з майбутньою спільною роботою братів Тобілевичів та Кропивницького в об’єднаній трупі корифеїв, яку було створено за кілька місяців потому.

В одній із кімнат старого будинку була так звана аптека, в котрій Надія Василівна, яка була за фахом лікарем, лікувала жителів навколишніх сіл та хуторів. Незрідка у вихідні та святкові дні, свідчить Володимир Кропивницький, у дворі стояла черга хворих: «хто приїзив кіньми, а хто й волами». Медична допомога селянам надавалась здебільшого безкоштовно. Іноді Надії Василівні доводилося робити своїм пацієнтам навіть нескладні операції [Кропивницький 1968 : 36].

Була в цьому будинку також своєрідна школа, у якій мати драматурга Капітоліна Іванівна навчала по неділях селян (дорослих і дітей) грамоти, арифметики та закону Божому. Якось 1896 року цю школу за наказом повітової влади було закрито. Після обшуку чиновники склали протокол із категоричним розпорядженням: «Надалі жодних занять із мужиками не проводити» [Кропивницький 1968 : 44]. Такий м’який на той час вердикт було винесено тільки з пошани до знаменитого на всю імперію артиста i зваживши на майже вісімдесятирічний вік його матері-вчительки.

Проте освітянська справа у Затишку не припинялась і після цієї неприємної події. Робилося це тільки значно обережніше. Заняття 3 селянськими дітьми проводили також син та донька письменника. Володя навчав хлопців, а Оля - дівчат. До навчання в садибі Кропивницьких всіляко заохочували. За словами колишньої учениці цієї школи Федори Семенівни Самойленко, тих, хто вчився добре, пригощали варенням або цукерками, а тим, що відставали, допомагали [Рукописний альбом 1959].

В останні роки свого життя Кропивницький був переповнений мрій про відкриття у Затишку школи 3 українською мовою навчання. Його дуже бентежить, що селяни погано сприймають український правопис. «Що ви вдієте, - скаржиться митецьь своєму знайомому, украӥнському літератору й видавцеві О. Коваленкові в листі від 23 січня 1909 року, - коли намого грамотія 
вчить р о с і й с в ка шк ол а, івін звикдо Ы, И і ґ». I далі провадить: «Писар із Сподобівки Петро, украӥнець, читав мені Шевченка так: "Думі мої, думі, ліхо мені з вамі". На превеликий жаль, Петро спершу у мене брав “Раду”, але через кілька номерів відрікся $i$ почав прохать “Южный край”» [Кропивницький $1960: 551-552]$.

I все ж таки задум Кропивницького навчати селян рідною мовою якоюсь мірою вдався. Так, у листі до згаданого вище О. Коваленка (січень 1909 року) письменник сповіщає: «Зараз в мене в хуторі вчіться чоловік з восьмеро дорослі, вчаться по украӥнських букварях, і иі вже читатимуть кулішівкою» [Кропивницький $1960: 551]$.

Неабияку увагу приділяв Кропивницький освіті власних дітей. Спочатку вони навчалися здебільшого вдома, задля чого драматург наймав репетиторів. За словами сина митця, в їхній сім’ї тривалий час мешкала гувернантка Еллі Юліївна Шеффер - «похилого віку німкеня» [Кропивницький 1968 : 76]. Саме вона, очевидно, й підготувала старшу доньку Олександру до вступу у п’ятий клас Вознесенської (німецької) гімназії у Харкові, де остання навчалася з 1901 по 1906 рік. До речі, навчаючись у гімназії, Олександра паралельно вдосконалювала свої музичні здібності, а згодом ще й вокальний хист. Упродовж трьох років вона брала приватні уроки фортепіано в одного з кращих тогочасних композиторів і музикантів - професора Альберта Бенша. Пізніше у неї було ще кілька відомих і «дорогих» учителів, у тому числі за кордоном.

Після закінчення 1905 року восьмирічної німецької гімназії мати повезла Олександру до Парижа, де дівчина брала уроки співів у мадам Роз Карон. Допоміг їй стати ученицею уславленої співачки видатний учений-фізіолог Ілля Мечников - добрий знайомий Кропивницького. За словами сина драматурга, він «послав Надію Василівну й Шуру з листом до К. Сен-Санса, а знаменитий маестро вже від себе дав рекомендаційного листа до Роз Карон» [Кропивницький 1968 : 120]. Одночасно у професора Тальберга Олександра навчалася по класу роялю. 
Практикувалися в родині драматурга й інші форми навчання. Для цього не шкодували жодних коштів i використовували щонайменшу нагоду. Описуючи у своїй книзі «Із сімейної хроніки Марка Кропивницького (Спогади про батька)» події, що відбувалися 1902 року, син митця згадував: «Коли ми були в батька минулої зими у Києві, то мене $і$ Олю віддали навчатися малюванню до якоїсь школи. Щодня ходили ми туди у супроводі намої няні Векли і проводили там години три, не більще. У ией приїзд для нас взяли репетитора студента Петра Тарасовича Радченка. Він займався з нами російською мовою і арифметикою, причому робив це дуже иікаво, так щзо я нетерпінням чекав завжди його уроків» [Кропивницький 1968 : 76].

Син Кропивницького Володимир середню освіту здобував так само в Харкові - в реальному училищі. Після цього за сімейною традицією він мав навчатися театральній справі, однак, на відміну від старшої сестри, на Імператорські драматичні курси в Петербурзі його не взяли через «малоросійський акцент». Поступив Володимир 1909 року на приватні курси у так звану Школу сценічного мистецтва Андрія Петровського, а пізніше закінчив ще й юридичний факультет Петербурзького університету.

Наймолодша донька Кропивницького Ольга упродовж року навчалась у Преображенській гімназії в Петербурзі, проте через загострення ревматизму змушена була 1909 року покинути північну столицю й поступити у Харківську жіночу гімназію Н. Григорцевич, яку закінчила 1912 року.

На початку нового XX століття (очевидно 3 метою полегшити перебування своїх дітей у Харкові) Кропивницькому спало на думку придбати в місті власний будинок. Варто звернути увагу на те, що з перших днів навчання Олександра «на повному пансіоні» жила в родині згаданого вже Дмитра Багалія. Нетривалий час після вступу до реального училища на таких же умовах мешкав тут і син Володимир.

Будинок у Харкові за адресою Лопатинський провулок, № 6 драматург купив навесні 1902 року. Попередня власниця у свій час обтяжила його кількома закладними, і відтепер термінові платіжні внески стали предметом 
додаткових турбот нових господарів. Сам Кропивницький у харківському помешканні майже не жив, а бував тут в основному наїздами. «Перший рік $y$ своєму новому будинку, - згадує письменників син, - ми жили на нижньому поверсі у квартирі з досить низькою стелею; в одній кімнаті стеля була зовсім похила; їдальня напівтемна... Це дало привід батьку, який приїздив до нас іноді y Харків, глузувати з непоказного вигляду наших “апартаментів” $i$ прозвати квартиру, де ми жили, “на дні”, за назвою відомої n’єси М. Горького» [Кропивницький $1968: 82]$.

Згодом родина переселилася на другий поверх, де квартира була зручніша й просторіша. Відомо, що тут незрідка гостювали колеги Кропивницького по сценічному мистецтву, а також родичі. При найменшій нагоді навідувалися сюди, зокрема, Костянтин Вукотич, прийомний син метра, та небіж Іван Мар'яненко (Петлішенко).

Сину Кропивницького запам'яталось, як у жовтні 1904 року у них гостював Іван Карпенко-Карий. В цей час у Харкові, в Малому театрі, 3 великим успіхом виставлялася його п’єса «Суєта». Пішла подивитися спектакль і Надія Кропивницька з молодшою донькою Ольгою. Після закінчення вистави за кулісами відбулася зустріч зі знайомими акторами. Саме тоді Надія Василівна й запросила драматурга до своєї оселі на обід [Кропивницький 1968 : 109]. Це була дуже тепла але, на жаль, уже остання зустріч двох давніх друзів. Пройде всього три роки, і Карпенка-Карого не стане, а ще через три відійде у вічність і Кропивницький.

Відвідувала харківське помешкання Кропивницького i прима українського театру Марія Заньковецька. «3 великим задоволенням пригадую, зауважує син драматурга, - щзо не один раз бувала в будинку Марія Костянтинівна. До батька і всієї нашої родини вона ставилась тепло й задушевно. Батька вона називала тоді “патер”. Бувало прийде до нас $i$, побачивши батька біля столу за роботою, завжди изілує його у вершечок голови. Марко Лукич, не відриваючись від справ, виявляв на обличчі иироку 
усмішку. Ці добрі стосунки із Заньковецькою зберігались у нас завжди» [Кропивницький 1968 : 92].

У цьому контексті доречно згадати, що в жовтні 1899 року, після бенефісу Кропивницького, уславлена акторка піднесла своєму не менш знаменитому вчителеві вінок із написом на стрічці: «Малороссийскому артисту-художнику от благодарной учениц̧ь М. К. Заньковецүкой». Вінок цей як найдорожча реліквія завжди зберігався в будинку у Затишку на одному 3 найпочесніший місць - поруч iз портретом Тараса Шевченка [Кропивницький 1968 : 59]. Прикрашував обійстя митця й великий портрет Заньковецької в ролі Олени - головної героїні драми Кропивницького «Глитай, або ж Павук».

Продав свій харківський будинок Кропивницький на початку літа 1907 року, оскільки, як зауважує його син, «зиск від нього не покривав витрат». Власне з 1905 року Кропивницькі в цьому будинку вже не мешкали, а здавали його в оренду. На гроші, виручені від продажу харківської оселі, митець придбав парову молотарку.

На особливу увагу заслуговує дитячий театр, який Кропивницький створив у Затишку в останні роки свого життя. Родзинка його полягає в тому, що грали в ньому діти місцевих селян, а також молодші діти метра Володя й Оля. Саме для цього свого малолітнього колективу драматург написав дві п’єси-казки «Івасик Телесик» і «По щучому велінню», в яких активно використав фольклорний матеріал. Цей театр користувався неабиякою популярністю. Про нього писала навіть столична преса.

Живучи у Затишку, Кропивницький досить часто виїздив на гастролі. Тому господарство вели в основному Надія Василівна та прикажчик. Проте в ті дні, коли драматург перебував у садибі, він із великим задоволенням поринав у сільське життя. Господарство у Кропивницьких за поміщицькими мірками було невелике. 1895 року воно налічувало, зокрема, шість корів, три пари волів, одинадцять коней, дванадцять овець, п’ятнадцять свиней, близько шістдесяти курей тощо. Відносно небагато було у Кропивницького й землі. В одному зі 
своїх листів до М. Аркаса (від 26 жовтня 1908 року) письменник сповіщає, що особисто він має двісті десятин та шістдесят вісім 3 половиною десятин одержала у спадок дружина. I далі зауважує: «...через полосна, кожен грош вкладаю в хазяйство, хазяйную, і тим дихаємо» [Кропивницький 1960 : 546].

Значно більше уваги господарству починає приділяти Кропивницький починаючи 3 весни 1903 року, коли після погіршення здоров’я перестає постійно виступати на професійній сцені й живе здебільшого у Затишку. 1909 року на виставці у повітовому місті Куп’янську за зразкове ведення господарства Кропивницького було нагороджено бронзовою медаллю Харківського товариства сільських господарів. У Куп’янському краєзнавчому музеї зберігається звіт, складений за підсумками цієї виставки. 3 цього звіту видно, що митець привіз на виставку чимало зразків різних плодових дерев та чубуків винограду, дещо з кращих сортів овочів та насіння, дві рамки меду, кілька мішків різних сортів пшениці, жита, вівсу, картоплі та черепицю власного виробництва.

Підсумовуючи, варто зауважити, що Затишок для Кропивницького був справжньою оазою. Тут він займався не лише господарськими справами, а й відпочивав душею, набирався натхнення для своєї багатогранної творчості. Його садиба на межі XIX-XX ст. була одним із найпотужніших національних культурних осередків, який відвідало чимало видатних особистостей. У себе на хуторі драматург започаткував одну 3 перших у тодішній країні школу 3 українською мовою навчання, дитячу трупу, аналогів якій не було в історії світового театру, оскільки в ролі акторів у ній виступали селянські діти. Разом iз національним професійним театром, який метр на теренах підросійської України заснував дещо раніше, все це сприяло утвердженню національної культури, наводило українців на думку про створення власної держави.

\section{БІБЛІОГРАФІЯ}

Кропивницький 1968 - Кропивницький В. М. Із сімейної хроніки Марка Кропивницького: (Спогади про батька) / В. М. Кропивницький. - Київ : Мистецтво, 1968. - 214 с. 
Кропивницький 1960 - Кропивницький М. Твори в 6-ти т. / Марко Кропивницький. - Київ : Держлітвидав УРСР, 1960. - Т. 6. - 672 с.

Рукописний альбом 1959 - Рукописний альбом спогадів про М. Кропивницького (Сподобівська загальноосвітня школа 1-2 ступенів імені М. Л. Кропивницького, Шевченківського району, Харківської області (записи зроблено П. Козарем наприкінці 1950-х років). 